\title{
Bilgi Teknolojileri ve Üst Yönetim Desteğinin Tedarik Zinciri Performansına Etkisi: Türkiye İçin Ampirik Bir Yaklaşım
}

\author{
Rahmi Baki ${ }^{1^{*}}$ \\ ${ }^{1}$ Aksaray Üniversitesi, İktisadi ve İdari Bilimler Fakültesi, Yönetim Bilişim Sistemleri Bölümü, Aksaray, Türkiye, (ORCID: 0000-0003-0981-5006)
}

(İlk Geliş Tarihi 13 Kasım 2019 ve Kabul Tarihi 7 Aralık 2019)

(DOI: $10.31590 /$ ejosat.654828)

ATIF/REFERENCE: Baki, R. (2019). Bilgi Teknolojileri ve Üst Yönetim Desteğinin Tedarik Zinciri Performansına Etkisi: Türkiye İçin Ampirik Bir Yaklaşım. Avrupa Bilim ve Teknoloji Dergisi, (17), 916-926.

$\ddot{O} \mathbf{z}$

Bilgi ve iletişim teknolojisi uygulamaları şirketler için bir vazgeçilmez ve yüksek tedarik zinciri performansının kilit belirleyicileri haline gelmiştir. Tedarik zinciri uygulamalarının başarısının artması için, tedarik zinciri boyunca bilgi teknolojileri faaliyetlerinin uygulanması hayati öneme sahiptir. Bilgi teknolojilerinin ileri düzeyde kullanımı, kurum içinde bilgi akışının, işbirliğinin ve iletişimin artmasına ve böylece tedarik zinciri performansının yükselmesine yol açacaktır. Bununla birlikte, bilgi teknolojilerinin uygulanması ve kullanılmasıyla ilgili üst düzey yönetim desteği, kuruluşlar arası bilgi paylaşımının verimliliğini arttırmakta ve böylece tedarik zinciri performansı üzerinde olumlu bir etki yaratmaktadır. Çalışmada bilgi teknolojileri, iç entegrasyon, üst yönetim desteği ve bilgi paylaşımı arasındaki ilişkiler ve tedarik zinciri performansına etkileri değerlendirilmektedir. $\mathrm{Bu}$ değerlendirmede test edilen hipotezler, SPSS AMOS yazılımında Yapısal Eşitlik Modellemesi kullanılarak Türkiye'deki firmalarda çalışan personellerden toplanan verilerle analiz edilmektedir. Örneklem, çeşitli sektörlerde çalş̧an (imalat, tekstil, inşaat, gıda ve lojistik) üst ve orta düzey yöneticilerden, uzmanlardan ve uzman yardımcılarından oluşmaktadır. Öne sürülen yapısal model, 103 çalışandan toplanan verilerle analiz edilmiştir. Bilgi teknolojilerinin iç entegrasyon üzerinde olumlu ve önemli bir etkiye sahip olduğunu gösteren analiz sonuçları, iç entegrasyon ile tedarik zinciri performansı arasında benzer bir ilişki bulunmadığını göstermektedir. Ayrıca, üst yönetim desteğinin bilgi paylaşımını önemli ölçüde ve olumlu yönde etkilediği sonucuna varılmışır. Buna ek olarak, bilgi paylaşımının tedarik zinciri performansı üzerinde olumlu bir etkisi vardır. Sonuç olarak, bu çalışma tedarik zinciri performanslarını geliştirmek isteyen firmalara rehberlik etmeyi amaçlamaktadır.

\section{The Impact of Information Technologies and Top Management Support on Supply Chain Performance: An Empirical Approach for Turkey}

\begin{abstract}
Applications of information and communication technologies have become indispensable for companies, being key determinants of high supply chain performance. Application of information technologies activities throughout the supply chain is vital for the increased success of supply chain applications. Advanced utilization of information technologies will lead to an increased level of information flow, cooperation and communication within the corporation, leading to integration and hence, a soaring up of supply chain performance. However, top management support regarding application and utilization of information technologies increases the
\end{abstract}

\footnotetext{
* Sorumlu Yazar: Aksaray Üniversitesi, İktisadi ve İdari Bilimler Fakültesi, Yönetim Bilişim Sistemleri Bölümü, Aksaray, Türkiye, ORCID: 00000003-0981-5006, rahmi.baki@hotmail.com
} 
efficiency of inter-organization information sharing, thus, creating a favourable impact over supply chain performance. This study assesses the relations between information technologies, internal integration, top management support and information sharing and their effects on supply chain performance. Hypotheses tested in this assessment are analyzed through data collected from personals working for firms in Turkey, via utilizing the Structural Equation Modelling in SPSS AMOS software. The sample consists of senior executives, mid-level managers, specialists and assistant specialists working in a span of sectors (manufacturing, textiles, construction, food and logistic). The structural model put forward is analyzed via data collected from 103 employees. Results of analyzing showing that information technologies has a positive and significant influence in internal integration whereas no similar relationship is prevalent between internal integration and supply chain performance. Moreover, concludes that top management support significantly and positively affects information sharing. In addition to this, information sharing has a positive effect on supply chain performance. All in all, this study aims to provide guidance for firms pursuing to develop their supply chain performance.

Keywords: Information and Communication Technologies, Information Systems, Supply Chain Management, Supply Chain Performance

\section{Introduction}

As a result of the rapid developments in information and communication technologies, companies have shifted their conventional strategies and as-is processes, since Information Technologies (IT) become a key indicator of successful supply chain management once it is used to integrate the activities of customers and suppliers (Bovel \& Martha, 2000). In other words, IT is considered to hold a critical influence in supply chain due to its contribution in improving both the company's performance and the successful execution of its supply chain activities (Jin, 2006).

Information flow, cooperation and communication is expected to be facilitated in companies that utilize IT effectively, allowing corporations to undertake their applications and processes in a synchronized manner and to keep the level of communication and coordination at the maximum. Nevertheless, it should also be put forward that recent literature lacks studies that assess the effect of information and communication technologies on companies' inter-company integration. This study aims to meet this need as it analyzes the relationship between IT and Internal Integration (II).

One can presume that firms which facilitate the integration among and cooperation of their departments will cater for their customers' needs in a more agile manner than their counterparts and shorten their lead time, resulting in the increased efficiency of their supply chain. Similarly, this study suggests that IT will lead into intra-company II, therefore leading to a higher supply chain performance.

Top Management Support (TMS) is a critical factor in the utilization and high performance of information and communication technologies in corporations. Tone-at-the-top, supporting IT usage in various departments and/or hierarchic levels eases the information sharing among the components of the supply chain, resulting in effective, complete and timely communication. In line with this lemma, this analysis also studies the relationship between TMS and IS.

Timely and complete communication and information sharing among the members of the supply chain is assumed to facilitate the effective decision making process regarding purchase orders, logistics and capacity allocation, thus triggering the high performance of the company. This study tests this assumption via putting forward the hypothesis that IS has a positive and significant influence over SCP.

Hypotheses tested in this assessment are analyzed through data collected from employees working for corporations based in Turkey, via utilizing the Structural Equation Modelling in SPSS AMOS software. The sample consists of senior executives, mid-level managers, specialists and assistant specialists working in a span of sectors (manufacturing, textiles, construction, fast-movingconsumer-goods and logistics). Then, hypotheses are evaluated based on the rigorous processing of data collected from a sample size of 103.

In summary, this study evaluates the inter-relationship between IT, II, TMS and IS, as well as their effect on SCP, aiming to provide a guiding light to firms pursuing efficiency and effectiveness in their supply chains, especially in Turkey and similar developing countries.

\section{Literature Review}

This study tests a conceptual model that analyses the relationship between IT, II, TMS, IS and SCP, where the latter is the strategic dependent variable. Model proposed hypothesizes that IT has a significant and positive effect on II.

In a similar assessment, Li, Yand, Sun and Sohal (2009) suggest that IT applications influence SCP both directly and through its integration with supply chain. After the testing of data collected from 182 Chinese companies, it has been concluded that while IT applications cannot be accepted to have a direct effect on SCP, their positive influence on supply chain integration has. Vickery, Jayaram, Droge and Calantone (2003) propose that an integrated supply chain strategy is constructed by two main determinants, integrative IT and supply chain integration. Their empirical analysis based on a sample consisting of 3 automobile suppliers in North America identifies a positive and significant relationship between integrated IT and supply chain integration. In another study, Su and Yang (2010) inspects data collected from 128 Taiwanese science-oriented corporations, finding out that strategic IT applications in supply chain management positively influence operational processes as well as customer and planning integration. 
The model proposes that II has a positive impact on SCP. Analogously, Gu, Jitpaipoon and Yang (2017) put forward that information system integration will trigger the producer's operational performance. Their research, focusing on a sample size of 220 collected from demand-driven-manufacturers embracing mass customization strategy, validates this lemma. Qi, Huo, Wang and Yeung (2017) base their study on 604 Chinese manufacturers and conclude that II has a significant impact on financial performance. Moreover, Lii and Kuo (2016), through their analysis of 480 surveys collected from corporations operating in Taiwan's electronics sector, assert and validate that II has a significant effect on both the ability and performance of a firm. In another assessment, Braunscheidel and Suresh (2009) study the pre-determinants of supply chain agility via scrutinizing 218 data gathered from the Institute for Supply Management, concluding that II to be one of the antecedents of supply chain agility. Li et al. (2009) accept the hypothesis that supply chain integration has a positive impact on SCP.

Another hypothesis tested in the model is that TMS has a positive influence on IS. In a study conducted by Youn, Yang, Hong and Park (2013), where responses gathered from 141 Korean manufacturers were assessed, it has been identified that TMS has a significant influence on strategic and operational IS. In addition, Byrd and Davidson (2003) base their research on 225 American corporations and put forward a significant relationship between TMS and IT in supply chain applications. Vargas, Mantilla and Jabbour (2018) scrutinize data collected from 126 employees working for firms based in Colombia, finding out that middle-to-top level management support increase firms' competitive advantage via facilitating social and environmental applications.

This study posits the lemma that IS has a positive and significant effect on SCP. In a similar assessment, Xu, Boh, Luo and Zheng (2018) analyze IS's influence on corporates' environmental performance and gather data from 205 firms operating in China, concluding that inter-organizational knowledge sharing has a significant and positive relationship with environmental cooperation and control of supply chain partners. Woo, Kim, Chung and Rho (2016) investigate communicative abilities for green SCP through the perspective of vendors. After carefully inspecting data gathered from 103 construction suppliers operating in Korea, they assert IS's positive influence on environmental cooperation, green cost reduction and corporal competitiveness. In a study based upon a sample containing of 141 Korean manufacturers, Youn et al. (2013) find out that strategic and operational IS to have a positive influence on environmental supply chain management among supply chain partners. Moreover, Youn, Yang and Hong (2012) identify IS's favorable impact on effective supply chain results on a strategic and operational level, after a rigorous analysis of data collected from 132 employees working for Korean corporations.

\section{Model Proposed and Hypotheses}

\subsection{Information Technologies (IT)}

Nowadays, IT has become a critical factor to transforming the way supply chain management activities are performed (Palmer \& Griffith, 1998). Application of IT activities throughout the supply chain is vital for the increased success of supply chain applications (Lai, Wong \& Cheng, 2006). Therefore, IT has been accepted as a strategic factor in supply chain due to its contributions to the rising performance of corporations and their supply chains (Li et al., 2009).

One of the fundamental objectives of supply chain management is the mitigation of uncertainty. IT helps corporates pursue this target via providing timely and accurate information regarding the existence of products, stock levels and shipping status (Radstaak \& Ketelaar, 2009). IT investments facilitate the information flow among departments and ameliorates the organizational structure (Kim \& Mahoney, 2006).

IT is a key proponent of supply chain integration as it eases the task of gathering and sharing of strategic information regarding business processes (Kelle \& Akbulut, 2005); and the application of IT in supply chain management facilitates the integration of product, information and finance flows among suppliers, producers and customers ( $\mathrm{Li}$ et al., 2009). Moreover, IT can manage information flow and create inter-connections that contribute to a heightened communication and cooperation among the supply chain (Brandyberry, Rai \& White, 1999). It is expected that firms that adeptly apply IT sources are relatively more talented in effectively coordinating certain operations in their internal and external supply chains (Setia \& Patel, 2013). IT bears the potential to alleviate the integration and coordination among supply chain partners through promoting the information sharing regarding demand forecasts and production plans, both of which are salient determinants of supply chain operations (Karoway, 1997).

In conclusion, it is presumed that advanced utilization of IT will lead to an increased level of information flow, cooperation and communication within the corporation, leading to II and hence, a soaring up of supply chain performance. Therefore, the following hypothesis can be put forward;

H1: Utilization of advanced IT has a positive and significant effect on II.

\subsection{Internal Integration (II)}

II emphasizes the communication and coordination among the departments of the corporation. Analogously, it can be described as the firm's level to operate its strategies, applications and processes with necessary cooperation and in a synchronized manner (Zhao, Huo, Selen \& Yeung, 2011). Integration is the result of a corporate's ability to construct a seamless process and facilitated information sharing.

The main target of supply chain integration is to construct a continuous and integrated system that include information and material flow shared both upstream and downstream (Towill, 1997). Examples of II include, but are not limited to, information sharing of different departments through utilizing enterprise resource planning systems upon dealing with sales orders, product 
development customized for consumers' needs, coordination and cooperation of R\&D, production and marketing departments (Huo, Ye, Zhao \& Shou, 2016).

All organizations comprising the supply chain should be managed as a unified system (Frohlich \& Westrook, 2001). This can only be attained if different components of the firm achieve a certain level of integration and coordination.

II helps firms avoid functional setbacks, eases the development of cooperation and attainment of operational performance (Huo et al., 2016). Sophisticated integration among the organizational units of a firm impacts a myriad of performance aspects such as cost, quality, delivery, agility and profits (Li et al., 2009). Ensuring supply chain integration is a strategic process that increases the value added of products, services and information (Lambert \& Cooper, 2000). Thus, integration has a crucial influence on corporate competitiveness (Lii \& Kuo, 2016).

All in all, a firm that can maintain a sustainable level of integration and cooperation among its organizational units can more agilely cater for its customers' needs, shorten the delivery time and improve its supply chain efficiency. Hence, the following hypothesis can be asserted;

H2: II has a positive and significant effect on SCP.

\subsection{Top Management Support (TMS)}

The independent variable, TMS, puts emphasis on Top Management's support of IT's effective application, usage and success in various organizational levels and units of the corporation.

TMS bears a strategic importance in the implementation of extended supply chain initiatives (Mentzer, DeWitt, Keebler, Min, Nix, Smith \& Zacharia, 2001), and tone-at-the-top regarding usage of IT applications is considered to be a key ingredient to a firm's success (Byrd \& Davidson, 2003). In summary, TMS is a vital factor in the operation, usage and success of IT applications in firms (Jarvenpaa \& Ives, 1990).

Top Management contributes to the integration of information sharing with corporate business strategy, therefore facilitating the effective application of supply chain management (Wu, Chiag, Wu \& Tu, 2004). For instance, top-level decisions allowing for the allocation of necessary budget for IT capacity is essential in easing the strategic and operational information sharing (Youn et al., 2013).

Additional examples to TMS can be put forward as investing in human capital vis-à-vis IT operations, revising business processes to reap the benefits of IT applications and financing research and development initiatives. All in all, tone-at-the-top regarding application and utilization of IT enhances and increases the efficiency of inter-organization information sharing, thus, creating a favourable impact over supply chain performance. The following hypothesis tests this lemma;

H3: TMS has a positive and significant effect on IS.

\subsection{Information Sharing (IS)}

Information sharing, from a supply chain perspective, represents the timely communication of supply chain partners (Green, Whitten \& Inman, 2007), where information sharing can be defined as the sharing of information in a timely, accurate and sufficient manner between those partners (Li, Rao, Ragu-Nathan \& Ragu-Nathan, 2005). Another definition asserts that IS is the level to sharing relevant, precise, comprehensive and classified information with its supply chain partners in a timely manner (Sheu, Rebecca Yen \& Chae, 2006).

Information sharing on a corporate basis occupies an essential place in the gathering of continuous and timely information (Zelbst, Green Jr, Sower \& Baker, 2010). Effective information sharing among supply chain partners have a positive influence on the fulfillment of supply chain applications (Zhou \& Benton, 2007). Sharing of value added information within the organization contributes to the enhancement of inter-organizational coordination and product quality (Pereira, 2009).

It can be safe to state that there exists a positive correlation between the intensity of the information shared and competitiveness of the firm. Acquiring, sharing and transmission of information among supply chain partners give rise to innovation and relative competitive advantage (Harland, Zheng, Johnsen \& Lamming, 2004). It facilitates the effectiveness of operations based on close cooperation, whereas direct information sharing leads to a better understanding of customers' and other firms' needs and thus, an increased level of catering for those requirements.

When information within the organization is apprised with supply chain partners, it is expected that more effective decisions can be made regarding sales-and-purchase orders, capacity allocation and materials substitution, and this will result in the increased efficiency of supply chain (Huang, Lau \& Mak, 2003). In conclusion, the sufficient, accurate and timely sharing of information among supply chain partners lead to a higher level of supply chain performance, supporting the hypothesis below. The overall model proposes is presented in Figure 1.

H4: IS has a positive and significant influence on SCP. 


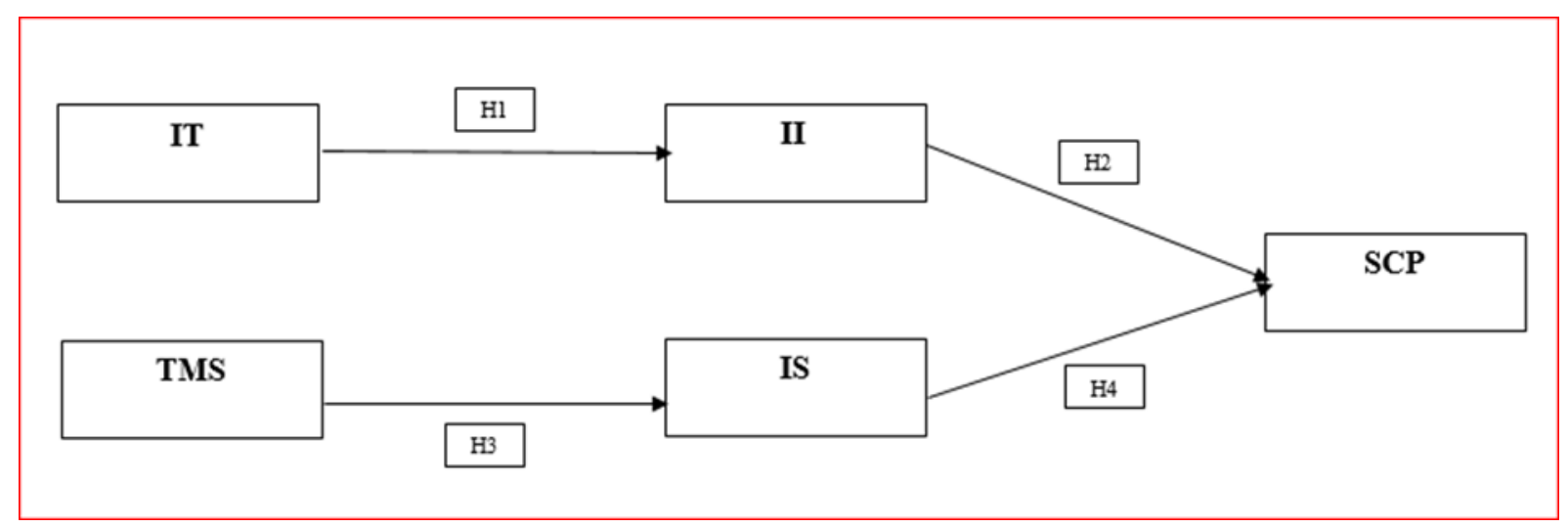

Figure 1. Proposed Model

\section{Research Methodology}

\subsection{Data Collection}

This study is based upon data collected from employees working for firms based in Turkey, where the sample consists of senior executives, mid-level managers, specialists and assistant specialists employed in firms operating in various sectors such as manufacturing, textiles, construction, fast-moving-consumer-goods and logistics. Priority is given to respondents who have a certain level of knowledge regarding their respective firms' supply chain activities.

The questionnaire has taken place during March - June 2019, during which surveys were sent to 250 employees via electronic mail and a total of 124 replies were received. Following the elimination of incomplete and inaccurate responses, a sample size of 103 were attained. Information regarding the respondents are presented in Table 1.

\section{Table 1. Firms and Participants Information}

\begin{tabular}{l|c|c}
\hline Classification & Frequency (n=103) & Percentage (\%) \\
\hline Industry Type & & 29.1 \\
\hline Manufacturing & 30 & 21.4 \\
\hline Textile & 22 & 18.4 \\
\hline Construction & 19 & 15.5 \\
\hline Food & 16 & 15.5 \\
\hline Logistic & 16 & 25.2 \\
\hline Number of Employees & & 11.7 \\
\hline$<50$ & 26 & 15.5 \\
\hline 50-100 & 12 & 12.6 \\
\hline 100-500 & 16 & 35 \\
\hline 500-1000 & 13 & 10.7 \\
\hline 1000 & 36 & 15.5 \\
\hline Job Title & & 27.2 \\
\hline Senior Executive & 11 & 46.6 \\
\hline Mid Level Manager & 16 & \\
\hline Expert & 28 & 40.8 \\
\hline Assistant Expert & 48 & 22.3 \\
\hline Seniority & & 19.4 \\
\hline$<3$ years & 42 & 17.5 \\
\hline 3-5 years & 23 & \\
\hline $5-10$ years & 20 & \\
\hline 10< years & 18 & \\
\hline
\end{tabular}

A literature-based survey was developed in order to be able to test the proposed model (Appendix A). Questions collected from previous research were translated into Turkish and were adopted to fit for relevance. The questionnaire consists of two sections: the first section comprises of 4 questions asked to identify the characteristics of respondents and their subsequent firms whereas the second section is formed of 37 Likert-type queries calculated on a five-fold scale. 


\subsection{Data Analysis}

Data collected from participants are analysed through Structural Equating Modelling via utilizing SPSS AMOS software. A twostep process is carried out where measurement model and structural model are evaluated respectively.

\subsubsection{Measurement Model}

The reliability of each item is assessed through its factor loading as common theory suggests that a reliable model should have factor loadings greater than 0.5 (Hair, Black \& Babin, 2010). As a result, the factor loadings of all variables proposed in this model are consistent with this lemma and vary between 0.571 (SCP 8) and 0.906 (II 2).

The convergent validity of the measurement model is tested via Confirmatory Factor Analysis, to find out whether a high level of correlation exists between the items of constructs tested in this step. Theory suggests that the Composite Reliability (CR) values of constructs should be higher than 0.7 for convergent validity (Hair, Anderson, Tatham \& Black, 1998). In line with this, the CR levels of all of the five constructs of the model proposed are higher than 0.7 and vary between 0.8 (TMS) and 0.888 (SCP).

Fornell and Larcker (1981) suggest that the Average Variance Extracted (AVE) value of each construct should be higher than 0.5, and the confirmatory factor analysis carried out for this model supports this lemma, as the AVE values of the constructs can be considered acceptable taking values within the range of 0.687 (IT) and 0.817 (II).

On a scale assessing internal reliability through Cornbach's Alpha values, coefficients higher than 0.90 are representative of perfect reliability, values ranging between $0.70-0.90$ and $0.50-0.70$ mean high and moderate reliability, respectively, whereas coefficients lower than 0.50 represent low reliability (Hinton, Brownlow, McMurray \& Cozens, 2004). Coefficients of structures tested in the model are above the acceptable limit offered by the theorem, as TMS (0.898), IS (0.890) and IT (0.834) show high reliability, while the coefficients of II (0.922) and SCP (0.921) are calculated to have perfect reliability (Table 2).

\subsubsection{Structural Model}

Common theory uses various indices to test the aptitude of the structural model, while the most frequently used indices in the literature reviewed within the scope of this study can be listed as $\lambda^{2} / \mathrm{df}$, RMSEA, SRMR TLI and CFI (Table 3). It has been assessed that the structural model has a satisfactory level of aptitude.

IT has a significant and positive impact on II $(\beta=0.669, \mathrm{p}=* * *)$, nevertheless no similar relationship exists between the latter variable and SCP $(\beta=-0.023, p=-0.789)$. It has been put forward that there is a significant interconnection between TMS and IS $(\beta=0.749, \mathrm{p}=* * *)$. Moreover IS is found out to have a robust impact on $\operatorname{SCP}(\beta=0.852, \mathrm{p}=* * *)$. All in all, while hypotheses 1,3 and 4 are not rejected; hypothesis 3 is (Table 4). The results of the hypotheses of the proposed model are presented in Figure 2.

Independent variables introduced explain $44.8 \%, 56.2 \%$ and $70.5 \%$ of II, IS and SCP respectively. The remaining can be attributed to indeterminate variables and errors.

\section{Results}

In order to test the hypotheses asserted in the model, data collected is analysed through Structural Equation Modelling via the utilization of SPSS AMOS software. The aptitude index levels of the proposed model are calculated to be $\lambda^{\wedge} 2 / \mathrm{df:}$ : 1.353, RMSEA: 0.059, SRMR:0.0699, TLI:0.911, CFI:0.919, as all of them are above the acceptable levels theorized by the previous literature (Table 3). Results of the structural model are given in Figure 2.

The analyses results of the structural model Show that TMS has a positive and significant impact on IS ( $\beta=0.749, p=* * *)$, and the latter variable is a direct determinant of SCP $(\beta=0.852, p=* * *)$, leading one to not reject the hypotheses 3 and 4 . In addition, even though a significant interrelation is found between IT and II $(\beta=0.669, \mathrm{p}=* * *)$, no such relationship is calculated to exist between II and $\operatorname{SCP}(\beta=-0.023, \mathrm{p}=0.789)$. Therefore hypothesis 2 is rejected while hypothesis 1 is not.

To conclude, it can be inferred from the testing results that Top Management Support influences the efficiency of information and data sharing, which leads to a heightened level of supply chain success. Moreover, effective usage of information and communication technologies contribute to inter-organizational integration. Unfortunately, this integration process cannot be shown to have an important impact on the supply chain performance.

\section{Discussion and Conclusion}

This study aims to uncover the relationship of four components (IT, II, TMS and IS) with SCP, hoping to provide a guiding light for corporations pursuing to attain and maintain a successful supply chain strategy.

Investments undertaken by corporates on information and communication technologies have expanded over time, however, it is still yet unclear whether these technologies have a direct and favourable effect on inter-organizational integration. This study proposes that advanced utilization of information and communication technologies will facilitate the information flow, communication and cooperation within the company. The results of the empirical analysis validate this lemma. 
Table 2. Outputs of Measurement Model

\begin{tabular}{|c|c|c|c|c|c|}
\hline Constructs & Item & Factor Loading & Cronbach's Alpha & $\mathbf{C R}$ & AVE \\
\hline \multirow{6}{*}{$I T$} & IT 1 & 0.637 & \multirow{6}{*}{0.834} & \multirow{6}{*}{0.804} & \multirow{6}{*}{0.687} \\
\hline & IT 2 & 0.611 & & & \\
\hline & IT 3 & 0.756 & & & \\
\hline & IT 4 & 0.642 & & & \\
\hline & IT 5 & 0.775 & & & \\
\hline & IT 6 & 0.701 & & & \\
\hline \multirow{6}{*}{ II } & II 1 & 0.853 & \multirow{6}{*}{0.922} & \multirow{6}{*}{0.831} & \multirow{6}{*}{0.817} \\
\hline & II 2 & 0.906 & & & \\
\hline & II 3 & 0.860 & & & \\
\hline & II 4 & 0.827 & & & \\
\hline & II 5 & 0.760 & & & \\
\hline & II 6 & 0.695 & & & \\
\hline \multirow{5}{*}{$T M S$} & TMS 1 & 0.794 & \multirow{5}{*}{0.898} & \multirow{5}{*}{0.800} & \multirow{5}{*}{0.799} \\
\hline & TMS 2 & 0.779 & & & \\
\hline & TMS 3 & 0.791 & & & \\
\hline & TMS 4 & 0.824 & & & \\
\hline & TMS 5 & 0.809 & & & \\
\hline \multirow{9}{*}{$I S$} & IS 1 & 0.666 & \multirow{9}{*}{0.890} & \multirow{9}{*}{0.862} & \multirow{9}{*}{0.692} \\
\hline & IS 2 & 0.817 & & & \\
\hline & IS 3 & 0.649 & & & \\
\hline & IS 4 & 0.665 & & & \\
\hline & IS 5 & 0.739 & & & \\
\hline & IS 6 & 0.706 & & & \\
\hline & IS 7 & 0.720 & & & \\
\hline & IS 8 & 0.656 & & & \\
\hline & IS 9 & 0.606 & & & \\
\hline \multirow{11}{*}{$S C P$} & SCP 1 & 0.711 & \multirow{11}{*}{0.921} & \multirow{11}{*}{0.888} & \multirow{11}{*}{0.721} \\
\hline & SCP 2 & 0.812 & & & \\
\hline & SCP 3 & 0.669 & & & \\
\hline & SCP 4 & 0.764 & & & \\
\hline & SCP 5 & 0.809 & & & \\
\hline & SCP 6 & 0.761 & & & \\
\hline & SCP 7 & 0.741 & & & \\
\hline & SCP 8 & 0.571 & & & \\
\hline & SCP 9 & 0.738 & & & \\
\hline & SCP 10 & 0.711 & & & \\
\hline & SCP 11 & 0.643 & & & \\
\hline
\end{tabular}

Ability of a company to sustain its strategies and operations with sufficient cooperation and in a synchronized manner is crucial in the continuity of the business processes. Previous research has tested the connection of inter-company integration to financial performance (Qi et al., 2017), competitiveness (Huo et al., 2016; Lii \& Kuo, 2016), corporate performance (Lii \& Kuo, 2016) and supply chain agility (Braunscheidel \& Suresh, 2009). This assessment hypothesises that coordination among organizational units have a favourable impact on the supply chain performance of the firm, yet fails to find out a significant relationship in the empirical tests.

Effective application and usage of information and communication technologies in a firm is thought to be facilitated by top management support. Tone-at-the-top contributes to the seamlessness of information sharing within the firm and its supply chain partners. Similarly, this model suggests that TMS has a positive impact on IS and provides the necessary empirical results to back this lemma.

Timely and accurate sharing of information among supply chain members is a key proponent of the effectiveness of the supply chain. One cannot expect the sustainability of a supply chain success unless information is shared in a timely and accurate manner with its supply chain partners. This study assesses the relationship between IS and SCP and discovers that IS has a favourable and significant influence on SCP. 
Table 3. Measurement Fit Indices

\begin{tabular}{l|c|c|c}
\hline Indices & Model & Recomended Values & References \\
\hline$\lambda^{2} / \mathrm{df}$ & 1.353 & $\leq 3$ & \multirow{3}{*}{ Hu and Bentler (1999), } \\
RMSEA & 0.059 & $<0.07$ & Kline (2005), Steiger \\
\cline { 1 - 3 } SRMR & 0.0699 & $<0.08$ & (2007) \\
\hline TLI & 0.911 & $>0.90$ & $>0.90$ \\
\hline CFI & 0.919 & & \\
\hline
\end{tabular}

Table 4. Hypotheses Testing Results

\begin{tabular}{|c|c|c|c|c|c|}
\hline Hypothesis & Independent Variable & Dependent Variable & Beta $(\beta)$ & p-value & \\
\hline 1 & IT & II & $\mathrm{p}<0.001$ & 0.669 & + \\
\hline 2 & II & SCP & 0.789 & -0.023 & + \\
\hline 3 & TMS & IS & $\mathrm{p}<0.001$ & 0.749 & - \\
\hline 4 & IS & SCP & $\mathrm{p}<0.001$ & 0.852 & + \\
\hline
\end{tabular}

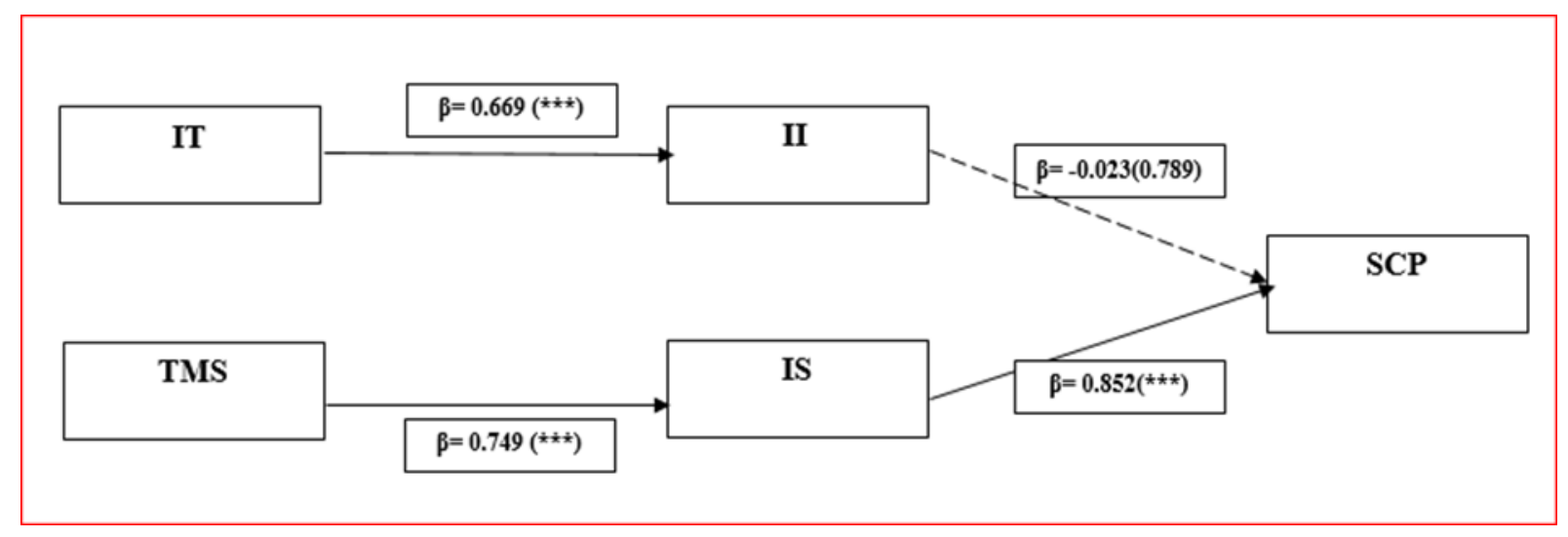

Figure 2. Final Model

The findings of the model can be rephrased as follows: Top Management's support of the utilization of information and communication technologies trigger the timely and accurate sharing of information among supply chain partners. Therefore a policy advice should revolve around facilitating the tone-at-the-top regarding the employees' usage of information and communication technologies via utilizing certain methods such as financing of IT development, investing on necessary and relevant human capital and re-designing business processes to reap the potential benefits of IT applications.

The assessment also identifies that timely and accurate sharing of information among supply chain partners has a positive impact on the effectiveness of supply chain. Seamless and robust information sharing facilitate effective decision making on a myriad of issues ranging from capacity allocation to materials substitution, hence leading to a heightened level of SCP. Moreover, the analysis also shows that effective IT utilization within the company has a favourable influence on inter-organizational communication and coordination.

Still, it should be noted that certain limitations exist in this model that should be taken into account in further research. For example, this study concentrates on the general description of IT, rather than focusing on a specific sub-category. Therefore, further research can be directed towards a certain group of IT users, to determine the varying effects of various IT users. Moreover, the model proposed in this paper is analysed with a sample containing employees working for five different sectors. Limiting the sample to a certain sector, and if possible, to a certain region and culture can provide interesting results. In addition, this model rejects the hypothesis that inter-company integration affects the supply chain performance. Further research can include external integration, process, customer and supplier integration as possible independent variables to explain supply chain performance. 


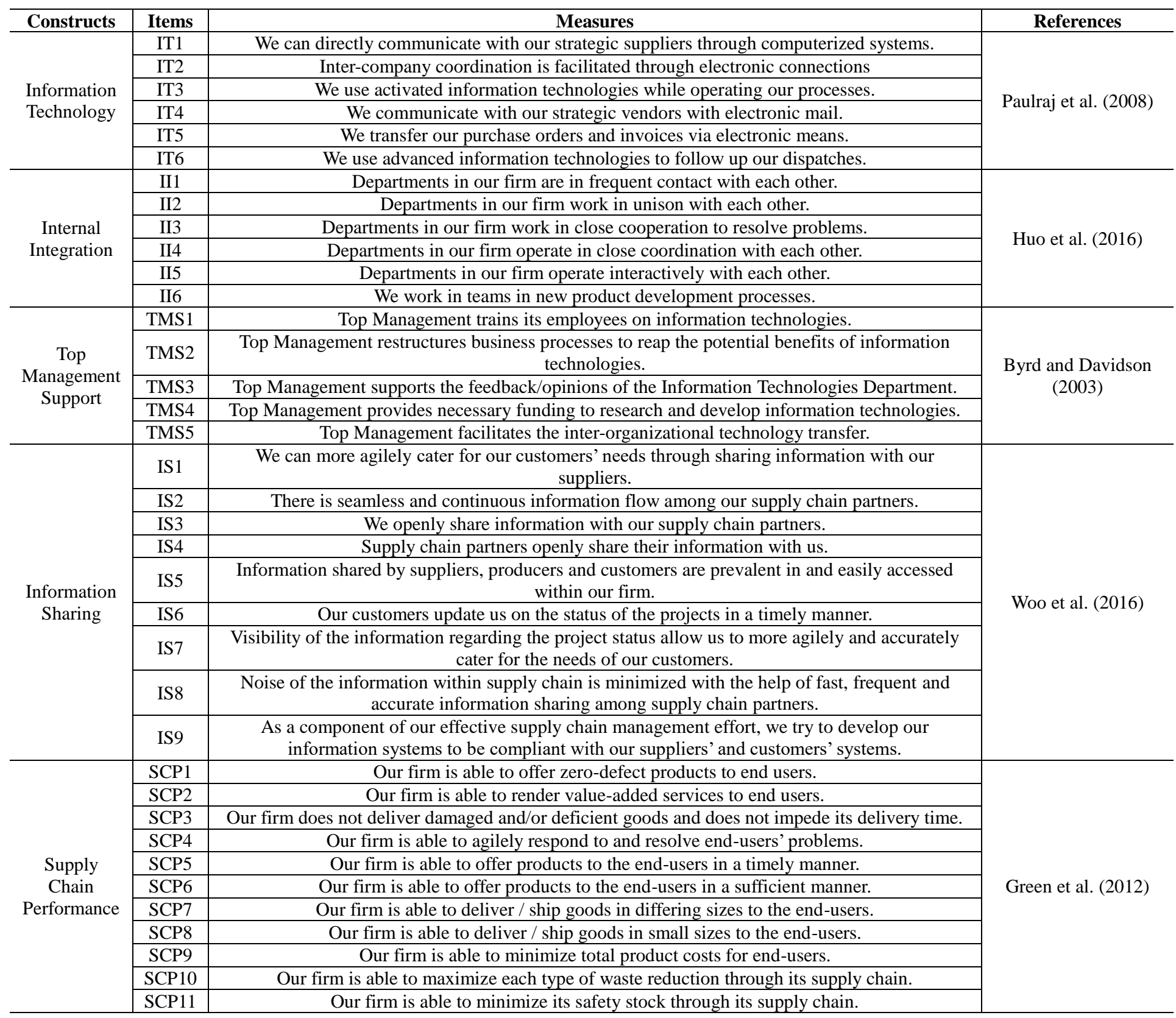

\section{References}

Bovel, D., \& Martha, J. (2000). From supply chain to value net. Journal of Business Strategy, 21(4), 24-28.

Brandyberry, A., Rai, A., \& White, G.P. (1999). Intermediate performance impacts of advanced manufacturing technology systems: An empirical investigation. Decision Sciences, 30(4), 993-1020.

Braunscheidel, M. J., \& Suresh, N. C. (2009). The organizational antecedents of a firm's supply chain agility for risk mitigation and response. Journal of Operations Management, 27(2), 119-140.

Byrd, T.A., \& Davidson, N.W. (2003). Examining possible antecedents of IT impact on the supply chain and its effect on firm performance. Information \& Management, 41(2), 243-255.

Frohlich, M.T., \& Westbrook, R. (2001). Arcs of integration: an international study of supply chain strategies. Journal of Operations Management, 19(2), 185-200.

Green Jr, K.W., Whitten, D., \& Inman, R.A. (2007). The impact of timely information on organisational performance in a supply chain. Production Planning \& Control, 18(4), 274-282.

Green Jr, K. W., Whitten, D., \& Inman, R. A. (2012). Aligning marketing strategies throughout the supply chain to enhance performance. Industrial Marketing Management, 41(6), 1008-1018.

Gu, Q., Jitpaipoon, T., \& Yang, J. (2017). The impact of information integration on financial performance: A knowledge-based view. International Journal of Production Economics, 191, 221-232.

Harland, C., Zheng, J., Johnsen, T., \& Lamming, R. (2004). A Conceptual Model for Researching the Creation and Operation of Supply Networks 1. British Journal of Management, 15(1), 1-21. 
Hu, L. T., \& Bentler, P. M. (1999). Cutoff criteria for fit indexes in covariance structure analysis: Conventional criteria versus new alternatives. Structural equation modeling: a multidisciplinary journal, 6(1), 1-55.

Huang, G.Q., Lau, J.S., \& Mak, K.L. (2003). The impacts of sharing production information on supply chain dynamics: A review of the literature. International Journal of Production Research, 41(7), 1483-1517.

Huo, B., Ye, Y., Zhao, X., \& Shou, Y. (2016). The impact of human capital on supply chain integration and competitive performance. International Journal of Production Economics, 178, 132-143.

Jarvenpaa, S. L., \& Ives, B. (1990). Information technology and corporate strategy: a view from the top. Information Systems Research, 1(4), 351-376.

Jin, B. (2006). Performance implications of information technology implementation in an apparel supply chain. Supply Chain Management: An International Journal, 11(4), 309-316.

Karoway, C. (1997). Superior supply chains pack plenty of byte. Purchasing Technology, 8(11), 32-35.

Kelle, P., \& Akbulut, A. (2005). The role of ERP tools in supply chain information sharing, cooperation, and cost optimization. International Journal of Production Economics, 93, 41-52.

Kim, S.M., \& Mahoney, J.T. (2006). Mutual commitment to support exchange: Relation-specific IT system as a substitute for managerial hierarchy. Strategic Management Journal, 27(5), 401-423.

Kline, R.B. (2005), Principles and Practice of Structural Equation Modeling (2nd Edition ed.). New York: The Guilford Press.

Lai, K.H., Wong, C.W., \& Cheng, T.E. (2006). Institutional isomorphism and the adoption of information technology for supply chain management. Computers in Industry, 57(1), 93-98.

Lambert, D. M., \& Cooper, M. C. (2000). Issues in supply chain management. Industrial Marketing Management, $29(1), 65-83$.

Li, G., Yang, H., Sun, L., \& Sohal, A.S. (2009). The impact of IT implementation on supply chain integration and performance. International Journal of Production Economics, 120(1), 125-138.

Li, S., Rao, S. S., Ragu-Nathan, T. S., \& Ragu-Nathan, B. (2005). Development and validation of a measurement instrument for studying supply chain management practices. Journal of Operations Management, 23(6), 618-641.

Lii, P., \& Kuo, F. I. (2016). Innovation-oriented supply chain integration for combined competitiveness and firm performance. International Journal of Production Economics, 174, 142-155.

Mentzer, J.T., DeWitt, W., Keebler, J.S., Min, S., Nix, N.W., Smith, C D., \& Zacharia, Z.G. (2001). Defining supply chain management. Journal of Business Logistics, 22(2), 1-25.

Palmer, J.W., \& Griffith, D.A. (1998). Information intensity: A paradigm for understanding web site design. Journal of Marketing Theory and Practice, 6(3), 38-42.

Paulraj, A., Lado, A. A., \& Chen, I. J. (2008). Inter-organizational communication as a relational competency: Antecedents and performance outcomes in collaborative buyer-supplier relationships. Journal of Operations Management, 26(1), 45-64.

Pereira, J. V. (2009). The new supply chain's frontier: Information management. International Journal of Information Management, 29(5), 372-379.

Qi, Y., Huo, B., Wang, Z., \& Yeung, H. Y. J. (2017). The impact of operations and supply chain strategies on integration and performance. International Journal of Production Economics, 185, 162-174.

Radstaak, B.G., \& Ketelaar, M.H. (1998). Worldwide Logistics: The Future of Supply Chain Services: Executive Summary, Conclusions and Major Findings. Holland International Distribution Council.

Setia, P., \& Patel, P.C. (2013). How information systems help create OM capabilities: Consequents and antecedents of operational absorptive capacity. Journal of Operations Management, 31(6), 409-431.

Sheu, C., Rebecca Yen, H., \& Chae, B. (2006). Determinants of supplier-retailer collaboration: Evidence from an international study. International Journal of Operations \& Production Management, 26(1), 24-49.

Steiger, J. H. (2007). Understanding the limitations of global fit assessment in structural equation modeling. Personality and Individual differences, 42(5), 893-898.

Su, Y. F., \& Yang, C. (2010). A structural equation model for analyzing the impact of ERP on SCM. Expert Systems with Applications, 37(1), 456-469.

Towill, D.R. (1997). The seamless supply chain-the predator's strategic advantage. International Journal of Technology Management, 13(1), 37-56.

Vargas, J. R. C., Mantilla, C. E. M., \& Jabbour, A. B. L. S. (2018). Enablers of sustainable supply chain management and its effect on competitive advantage in the Colombian context. Resources, Conservation and Recycling, 139, 237-250.

Vickery, S. K., Jayaram, J., Droge, C., \& Calantone, R. (2003). The effects of an integrative supply chain strategy on customer service and financial performance: an analysis of direct versus indirect relationships. Journal of operations management, 21(5), 523-539.

Woo, C., Kim, M.G., Chung, Y., \& Rho, J.J. (2016). Suppliers' communication capability and external green integration for green and financial performance in Korean construction industry. Journal of Cleaner Production, 112, 483-493.

Wu, W.Y., Chiag, C.Y., Wu, Y.J., \& Tu, H.J. (2004). The influencing factors of commitment and business integration on supply chain management. Industrial Management \& Data Systems, 104(4), 322-333.

Xu, Y., Boh, W. F., Luo, C., \& Zheng, H. (2018). Leveraging industry standards to improve the environmental sustainability of a supply chain. Electronic Commerce Research and Applications, 27, 90-105.

Youn, S., Yang, M. G. M., \& Hong, P. (2012). Integrative leadership for effective supply chain implementation: An empirical study of Korean firms. International Journal of Production Economics, 139(1), 237-246.

Youn, S., Yang, M.G.M., Hong, P., \& Park, K. (2013). Strategic supply chain partnership, environmental supply chain management practices, and performance outcomes: an empirical study of Korean firms. Journal of Cleaner Production, 56, 121-130.

Zelbst, P. J., Green Jr, K.W., Sower, V.E., \& Baker, G. (2010). RFID utilization and information sharing: The impact on supply chain performance. Journal of Business \& Industrial Marketing, 25(8), 582-589. 


\section{Avrupa Bilim ve Teknoloji Dergisi}

Zhao, X., Huo, B., Selen, W., \& Yeung, J.H.Y. (2011). The impact of internal integration and relationship commitment on external integration. Journal of Operations Management, 29(1-2), 17-32.

Zhou, H., \& Benton Jr, W.C. (2007). Supply chain practice and information sharing. Journal of Operations Management, 25(6), 13481365. 